\title{
Photochemical Damage and Responses of Antioxidant Enzymes in Rice Leaves Induced to Light-Chilling
}

Jeung Suk Koo, Yeon Sik Choo ${ }^{1}$ and Chin Bum Lee*

Department of Molecular Biology, Dong-eui University, Busan 614-714, Korea

${ }^{1}$ Department of Biology, Kyungpook National University, Daegu 702-701, Korea

Received February 6, 2009 / Accepted February 12, 2009

We investigated photooxidation and responses of antioxidant enzymes involved in scavenging reactive oxygen species (ROS) after light-chilling $\left(4^{\circ} \mathrm{C}\right)$ for 2 days and post chilling $\left(25^{\circ} \mathrm{C}\right)$ in rice leaves. Chilling leaves indicated a $50 \%$ reduction in photosynthetic efficiency $\left(\mathrm{F}_{\mathrm{v}} / \mathrm{F}_{\mathrm{m}}\right.$ ratio) and a $48 \%$ increase of $\mathrm{H}_{2} \mathrm{O}_{2}$, respectively, compared to the control group. In comparison with the control, activities of superoxide dismutase (SOD) and glutathione reductase (GR) increased at light-chilling and post-chilling. CuZn-SOD and Mn-SOD among SOD forms were detected in rice leaves, while Fe-SOD was not found. The increase of SOD and GR activity may serve as a basis for defense against chilling injury as it dismutase superoxide generated by light-chilling. Catalase (CAT) activity decreased during light-chilling, while activity of APX showed remarkable increase during light-chilling in rice leaves. Among CAT isoforms analyzed by 10\% native PAGE, activities of isoform -2 and -3 were inhibited during light-chilling. From the elevated APX activity and decreased CAT activity, we suggest that these two enzymes show mutual supplementary relationships, indicating different tendency during light-chilling.

Key words : Chilling, $\mathrm{H}_{2} \mathrm{O}_{2}, \mathrm{~F}_{\mathrm{v}} / \mathrm{F}_{\mathrm{m}}$, rice, ROS scavenging enzymes

\section{Introduction}

In nature, plants experience abiotic stresses when exposed to various environmental factors such as light, water and temperature deviated from appropriate ranges. Soil and water salinity are raising problems facing rice production $[13,26]$. Also, rice is not adapted to low temperature and is damaged by temperatures below $15^{\circ} \mathrm{C}$ [16]. Many crop species including rice are sensitive to chilling $[2,17,25,29]$. to chilling undergo much severe damages when exposed to low temperature in combination with irradiation $[19,20]$. Photoinhibition occurs as an initial response to primary damage by low temperature $[4,14]$. Photosynthetic damage and disturbances are basically caused by ROS formation and its visual symptoms can be detected by necrotic lesions on the surface of leaf $[1,5]$. However, in spite of no visual symptoms with short-term exposure to chilling, injury can be manifested gradually when plants return to normal growth temperature. Therefore, it is helpful in rapid screening stress tolerance of rice [17]. One of the main causes of chilling injury is ROS generation during light-chilling including photo-

\footnotetext{
${ }^{*}$ Corresponding author

Tel : +82-51-890-1525, Fax : +82-51-890-1521

E-mail : cblee@deu.ac.kr
}

oxidation [28]. In general, plants facing to ROS generation have very intensive antioxidant scavenging systems. For example, low-molecular weight antioxidants such as ascorbate and glutathione act directly against oxygen free radicals to scavenge their toxicity with the help of antioxidant enzymes such as SOD, CAT and peroxidase (POX). The initial ROS scavenging enzyme is SOD. Higher plants have three types of SOD which convert $\mathrm{O}_{2}^{-}$into $\mathrm{H}_{2} \mathrm{O}_{2}$ and $\mathrm{O}_{2}$ [32]. As $\mathrm{H}_{2} \mathrm{O}_{2}$ generated from SOD reaction is harmful, CAT or POX detoxify it into $\mathrm{H}_{2} \mathrm{O}$ and $\mathrm{O}_{2}$. APX, more important than other ROS scavengers is an essential component of ascorbate-glutathione pathway removing ROS generated through photosynthesis. Similar pathway also exists in the cytosol of leaf cells [3]. Guo et al. [15] have reported that APX activity increased in both drought- and chilling- tolerant rice cultivars. Ascorbate-glutathione pathway includes APX which uses ascorbate as a substrate with GR. Increase in GR activity during salt stress was observed in rice and during cold stress in pea $[10,22]$. Additionally, it was reported repeatedly that GR is important in oxidative stress [31]. Functional interaction of the enzymes is important to effectively scavenge ROS. Studies on chilling have been widely conducted for chilling-sensitive varieties as well as chilling-tolerant varieties in relation to production of grain crops including rice $[12,17,27,30]$. In the present work, we inves- 
tigated photooxidation after light-chilling $\left(4^{\circ} \mathrm{C}\right)$ for 2 days and post-chilling $\left(25^{\circ} \mathrm{C}\right)$ for 2 days by carrying out chlorophyll fluorescence analysis. We also investigated activities of antioxidant enzymes involved in scavenging ROS during light-chilling and post-chilling.

\section{Material and Methods}

\section{Plant material}

Surface-sterilized seed coats of japonica type rice (Oryza sativa L. cv. Dongjin) were germinated in water for 5 days at $25^{\circ} \mathrm{C}$ under dark conditions. After germination, seedlings were grown in a growth chamber for 15 days. The growth condition was composed of temperature of $25^{\circ} \mathrm{C}$, relative humidity of $70 \%$ and photoperiod of $14 \mathrm{hr}(150 \mu \mathrm{mol}$ quanta $\mathrm{m}^{-2} \mathrm{~s}^{-1}$ ). The leaves of 15 day-grown rice seedling (about 12 $15 \mathrm{~cm}$ ) were detached and exposed to $4^{\circ} \mathrm{C}$ for 2 days (light-chilling). After this period, leaves were subsequent recovered at $25^{\circ} \mathrm{C}$ for 2 days (post-chilling). At the end of the treatments, 10 plants of each treatment were frozen in liquid nitrogen and kept at $-80^{\circ} \mathrm{C}$ until processed for analyses. Each time, $1 \mathrm{~g}$ of leaf samples collected from 10 plants were used for enzyme activity analyses.

\section{Chlorophyll fluorescence analysis}

Chlorophyll fluorescence was measured using a photosynthesis yield analyzer (Portable Chlorophyll Fluorometer PAM-2000, Walz, Germany). Modulated chlorophyll fluorescence was measured from the dark-adapted leaves of rice with an excitation light intensity of $200 \mu \mathrm{mol}$ quanta $\mathrm{m}^{-2} \mathrm{~s}^{-1}$. Measurements were carried out in dark-adapted leaves after 30 min of dark period. $F_{0}, F_{m}$, and $F_{m}{ }^{\prime}$ were recorded and optimal quantum yield of photosystem II $\left(F_{v} / F_{m}\right.$, where $F_{v}$ is $\left.F_{m}-F_{0}\right)$ were calculated as described by Lee et al. [21]. Also, the rate constant of non-photochemistry process (fluorescence, heat emission, and energy transfer to PS I , 1/ $\left.F_{m}{ }^{\prime}\right)$ was calculated according to Lee et al. [21].

\section{Estimation of $\mathrm{H}_{2} \mathrm{O}_{2}$ level}

$\mathrm{H}_{2} \mathrm{O}_{2}$ levels of rice leaves were estimated according to the modified method of Lee et al. [21]. Leaves $(1 \mathrm{~g})$ were homogenized in $100 \mathrm{mM}$ sodium phosphate buffer ( $\mathrm{pH}$ 7.0). The homogenate was filtered through four layers of cheesecloth and centrifuged at $18,000 \times \mathrm{g}$ at $4^{\circ} \mathrm{C}$ for $20 \mathrm{~min}$. An aliquot $(0.5 \mathrm{ml})$ of supernatant was mixed with $2.5 \mathrm{ml}$ of peroxide reagent consisting of $83 \mathrm{mM}$ sodium phosphate $(\mathrm{pH} 7.0)$,
$0.005 \%(\mathrm{w} / \mathrm{v})$ o-dianisidine, 5 unit peroxidase (Sigma, USA) followed by incubation at $30^{\circ} \mathrm{C}$ for $10 \mathrm{~min}$. The reaction was stopped by adding $0.5 \mathrm{ml}$ of $1 \mathrm{~N}$ perchloric acid and centrifuged at $3,000 \times \mathrm{g}$ for $5 \mathrm{~min}$. The absorbance of the supernatant was read at $436 \mathrm{~nm}$, which was compared to the extinction of a $\mathrm{H}_{2} \mathrm{O}_{2}$ standard.

\section{Preparation of enzyme extracts}

Frozen tissues (10 plants of each treatment are used measuring $1 \mathrm{~g}$ ) were ground with a pestle in a cold mortar with liquid $\mathrm{N}_{2}$. Fresh Soluble proteins were extracted by suspending the powder in $4 \mathrm{ml}$ of $100 \mathrm{mM}$ potassium phosphate buffer ( $\mathrm{pH} 7.8$ ), containing $0.1 \mathrm{mM}$ EDTA, 1\% PVP-40, and $0.5 \%$ Triton X-100. For analysis of APX, the extraction buffer also contained $5 \mathrm{mM}$ ascorbate. The homogenate was filtered through four layers of cheesecloth and centrifuged at $18,000 \times \mathrm{g}$ at $4^{\circ} \mathrm{C}$ for $20 \mathrm{~min}$. The supernatant was used for determination of antioxidant enzymes activities. Protein content was measured according to Lowry et al. [23]. All measurements were repeated 3-5 times.

\section{Assay of enzymes activities}

Determination of SOD activity was performed according to Beyer and Fridovich [7]. The reaction mixture of $25 \mathrm{ml}$ was composed of $50 \mathrm{mM}$ potassium phosphate buffer $(\mathrm{pH}$ 7.8), $9.9 \mathrm{mM}$ methionine, $57 \mathrm{mM}$ nitroblue tetrazolium (NBT) and the appropriate volume of plant extract. The reaction was initiated by light illumination. One unit of SOD is defined as the amount of enzyme which causes a $50 \%$ decrease of the SOD-inhibitory NBT reduction. SOD activity was determined at $560 \mathrm{~nm}$. CAT activity was determined by monitoring the decomposition of $\mathrm{H}_{2} \mathrm{O}_{2}$ (extinction coefficient 39.4 $\mathrm{mM} \mathrm{cm}^{-1}$ ) at $240 \mathrm{~nm}$ following the method of Lee et al. [21]. The reaction mixture contained $50 \mathrm{mM}$ potassium phosphate buffer ( $\mathrm{pH} \mathrm{7.0)}$ and plant extract in $3 \mathrm{ml}$ volume. The reaction was initiated by adding $10 \mathrm{mM} \mathrm{H}_{2} \mathrm{O}_{2}$. One unit of catalase is defined as the amount of enzyme which liberates half the oxygen peroxide from $10 \mathrm{mM} \mathrm{H}_{2} \mathrm{O}_{2}$ solution in 100 $\mathrm{S}$ at $25^{\circ} \mathrm{C}$. APX activity was determined following the decrease of absorbance at $290 \mathrm{~nm}$ (extinction coefficient $2.8 \mathrm{mM}$ $\mathrm{cm}^{-1}$ ) [7]. The reaction mixture contained $50 \mathrm{mM}$ potassium phosphate buffer ( $\mathrm{pH} 7.0$ ), $0.5 \mathrm{mM}$ ascorbate, $0.2 \mathrm{mM} \mathrm{H}_{2} \mathrm{O}_{2}$ and the suitable volume of enzyme extract. GR activity was determined by the fall in absorbance at $340 \mathrm{~nm}$ by NADPH oxidation in the presence of GSSG, following the procedure of Lee et al. [21]. The reaction mixture contained $100 \mathrm{mM}$ 
potassium phosphate buffer ( $\mathrm{pH} 7.8), 2 \mathrm{mM}$ EDTA, $0.5 \mathrm{mM}$ GSSG and extracts. The reaction was initiated by adding 0.2 $\mathrm{mM}$ NADPH. One unit of GR is defined as the amount of enzyme which oxidizes $1 \mu \mathrm{mol}$ of NADPH per min at $25^{\circ} \mathrm{C}$.

\section{PAGE analysis of enzymes activities}

Activated of SOD, CAT, APX and GR were determined following the procedure of Lee et al. [21]. Plant extracts containing equal amounts of protein, with the addition of bromophenol blue and glycerol to a final concentration of $12.5 \%$, were subjected to discontinuous PAGE under non-denaturing, nonreducing conditions, except that SDS was omitted and the gels were supported by $10 \%$ glycerol. Electrophoresis was performed at $4^{\circ} \mathrm{C}$ for $4 \mathrm{hr}$ with a constant current of $30 \mathrm{~mA}$. For the analysis of APX activity, $2 \mathrm{mM}$ ascorbate was added to the electrode buffer and the gel was pre-run for $30 \mathrm{~min}$ before the samples were loaded. SOD activity was detected following the modified procedure of Beauchamp and Fridovich [6]. Identification of SOD isoforms was achieved by incubating gels in $50 \mathrm{mM}$ potassium phosphate buffer ( $\mathrm{pH} 7.0$ ) containing $3 \mathrm{mM} \mathrm{KCN}$ or $5 \mathrm{mM}$ $\mathrm{H}_{2} \mathrm{O}_{2}$ for 30 min before staining SOD.
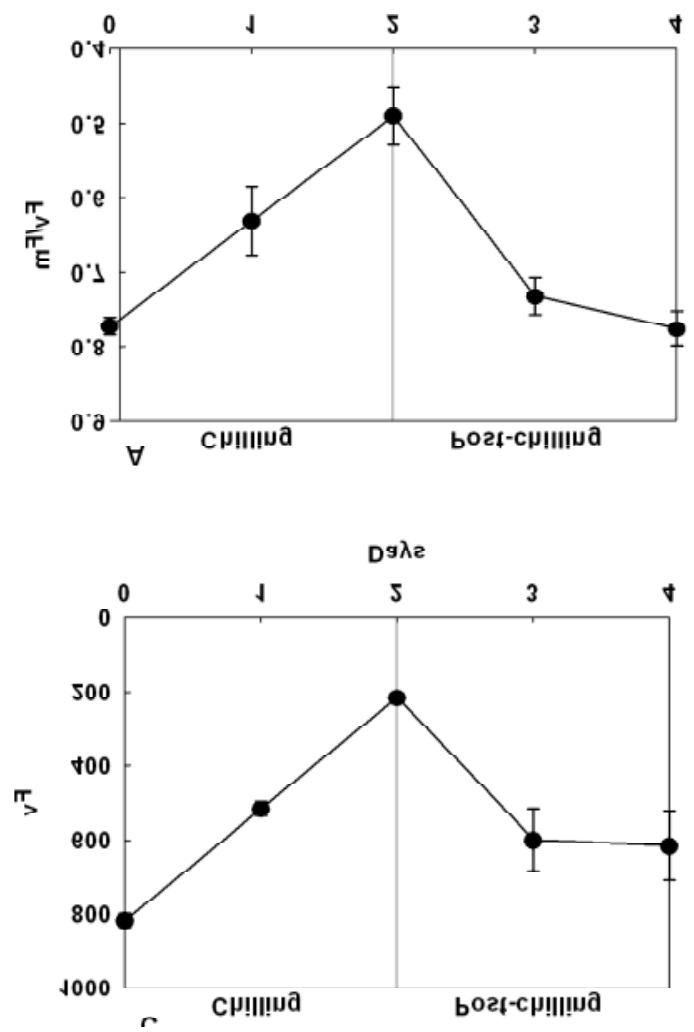

Results

\section{Chilling-induced oxidative stress symptoms}

To study chilling-induced injury symptoms of rice leaves, we measured photochemical efficiency $\left(\mathrm{F}_{\mathrm{v}} / \mathrm{F}_{\mathrm{m}}\right)$ and photochemical parameters $\left(F_{0}, F_{v}, F_{m}\right)$ which had been exposed to light-chilling and post-chilling (Fig. 1). Photosynthetic efficiency in terms of $F_{v} / F_{m}$ ratio gradually decreased during chilling (Fig. 1A). Ratio of $\mathrm{F}_{\mathrm{v}} / \mathrm{F}_{\mathrm{m}}$ reduced by $50 \%$ during chilling compared with control. However, the ratio of $F_{v} / F_{m}$ was restored rapidly during post-chilling. In contrast, $F_{0}$ (minimum level of fluorescence yield) showed no significant changes during chilling and post-chilling (Fig. 1B). Chilling reduced variable fluorescence $\left(\mathrm{F}_{\mathrm{v}}\right)$ and maximal fluorescence $\left(\mathrm{F}_{\mathrm{m}}\right)$ (Fig. 1C and 1D). Reduction of $\mathrm{F}_{\mathrm{v}} / \mathrm{F}_{\mathrm{m}}$ ratio by chilling was examined to be due to decrease of $F_{v}$. Rate constants of non-photochemistry process $\left(1 / \mathrm{F}_{\mathrm{m}}\right)$ increased during chilling and was recovered quickly during post-chilling (Fig. 2). Chilling-induced oxidative stress symptoms are shown as changes in the amount of $\mathrm{H}_{2} \mathrm{O}_{2}$ in rice leaves (Fig. 3). Light-chilling induced increase of the amount of $\mathrm{H}_{2} \mathrm{O}_{2}$ by $48 \%$ with compared with control, but subsequently recov-
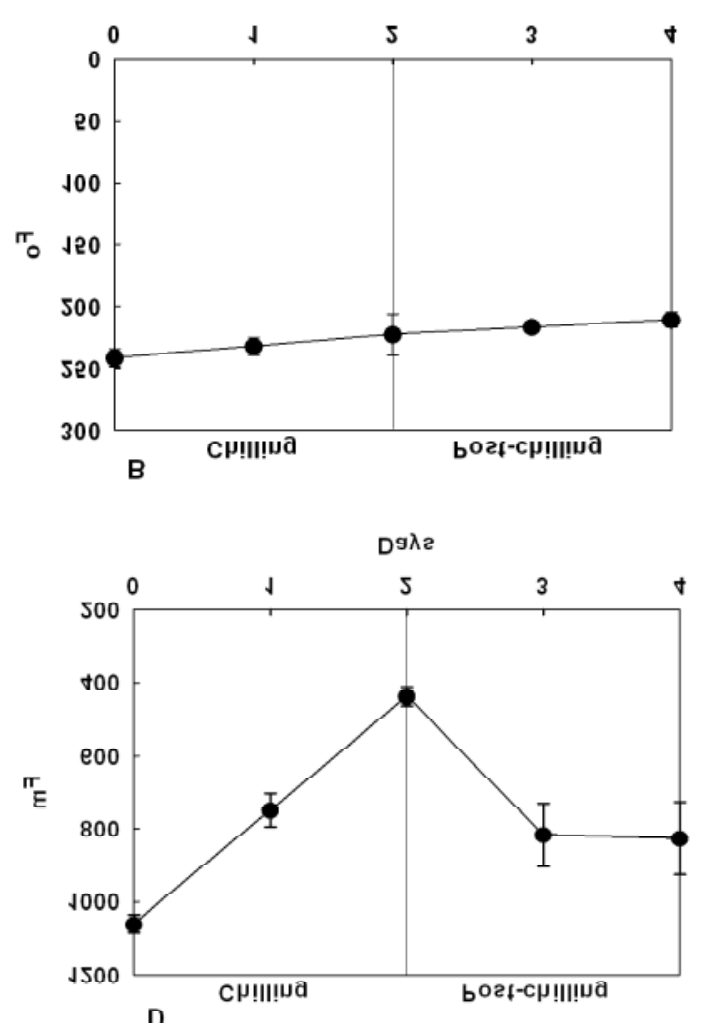

Fig. 1. Photochemical parameters that had been subjected to $4^{\circ} \mathrm{C}$ for 2 days (chilling) and subsequently recovered at $25^{\circ} \mathrm{C}$ for 2 days (post-chilling) in the rice leaves. A, Photosynthetic efficiency $\left(\mathrm{F}_{\mathrm{v}} / \mathrm{F}_{\mathrm{m}}\right) ; \mathrm{B}$, Minimal quantum yield $\left(\mathrm{F}_{\mathrm{o}}\right)$; $\mathrm{C}$, Variable fluorescence $\left(F_{v}\right) ; D$, Maximal fluorescence $\left(F_{m}\right)$. The values represent mean \pm S.D. $(n=6)$. 


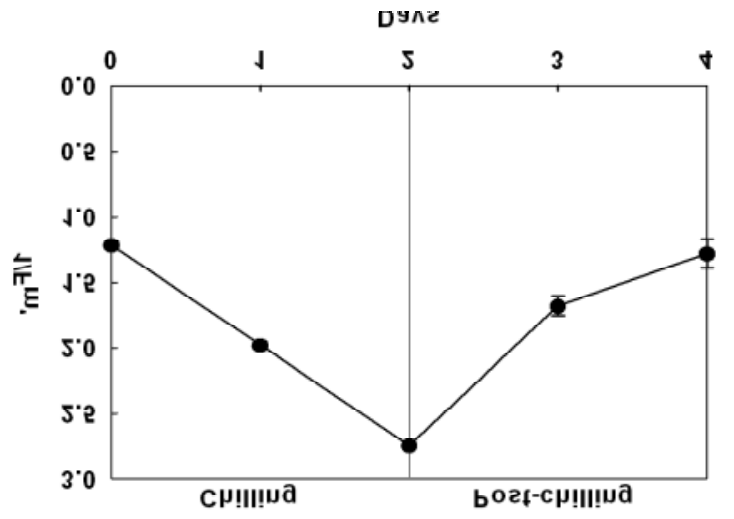

Fig. 2. Rate constants of non-photochemistry process $\left(1 / \mathrm{F}_{\mathrm{m}}{ }^{\prime}\right)$ that had been subjected to $4^{\circ} \mathrm{C}$ for 2 days (chilling) and subsequently recovered at $25^{\circ} \mathrm{C}$ for 2 days (post-chilling) in the rice leaves. The values represent mean \pm S.D. $(n=6)$.

ered during post-chilling.

Changes of activities of antioxidant enzymes in rice leaves

Activaties of SOD, CAT, APX and GR were shown Fig. 4. SOD converts ROS into $\mathrm{H}_{2} \mathrm{O}_{2}$ and $\mathrm{O}_{2}$. When compared with control, total SOD activities increased about $49 \%$ dur-
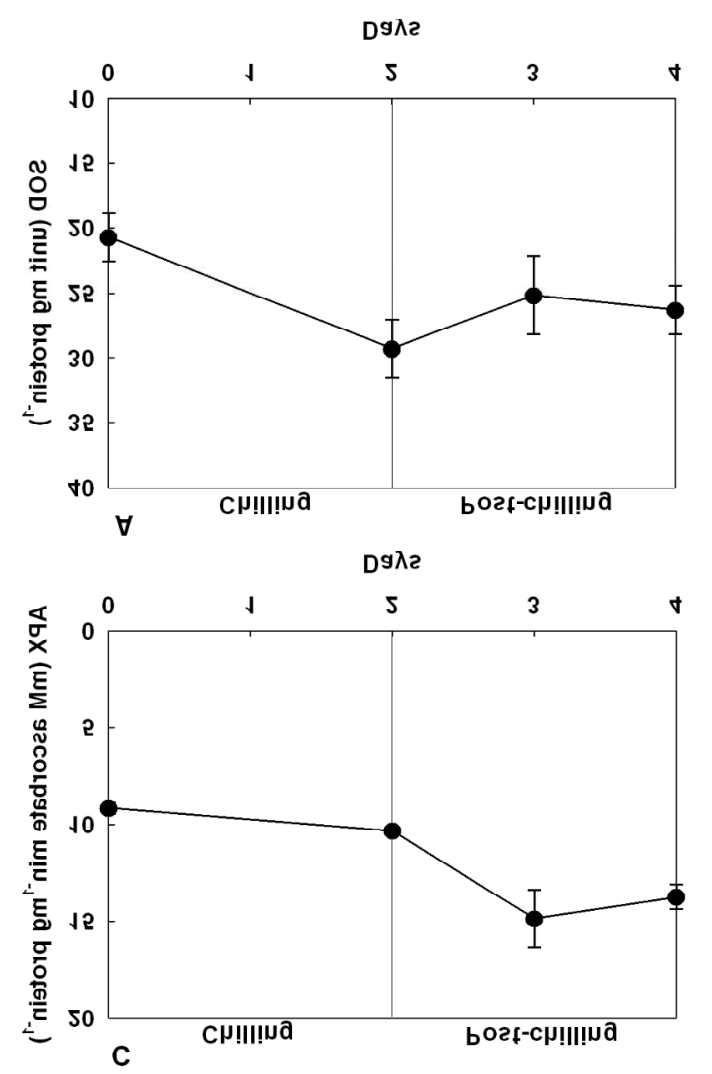

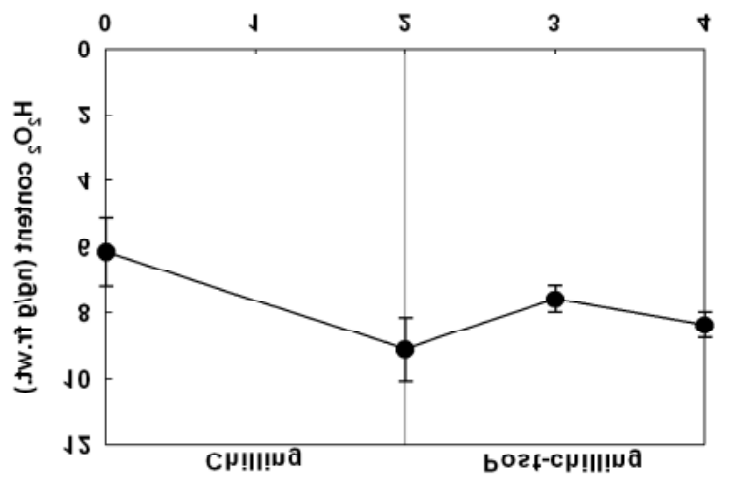

Fig. 3. Change of the $\mathrm{H}_{2} \mathrm{O}_{2}$ contents that had been subjected to chilling and post-chilling in the rice leaves. The values represent mean \pm S.D. $(n=6)$.

ing light-chilling and the same tendency showed in the post-chilling in the rice leaves (Fig. 4A). CAT showed decreased activities during light-chilling (Fig. 4B). CAT showed rather decrease of $63 \%$ during light-chilling that is consistent with general tendency of CAT activity in response to low temperature. Declined CAT activities after chilling for 2 days might be originated from the enzymes sensitivity to low
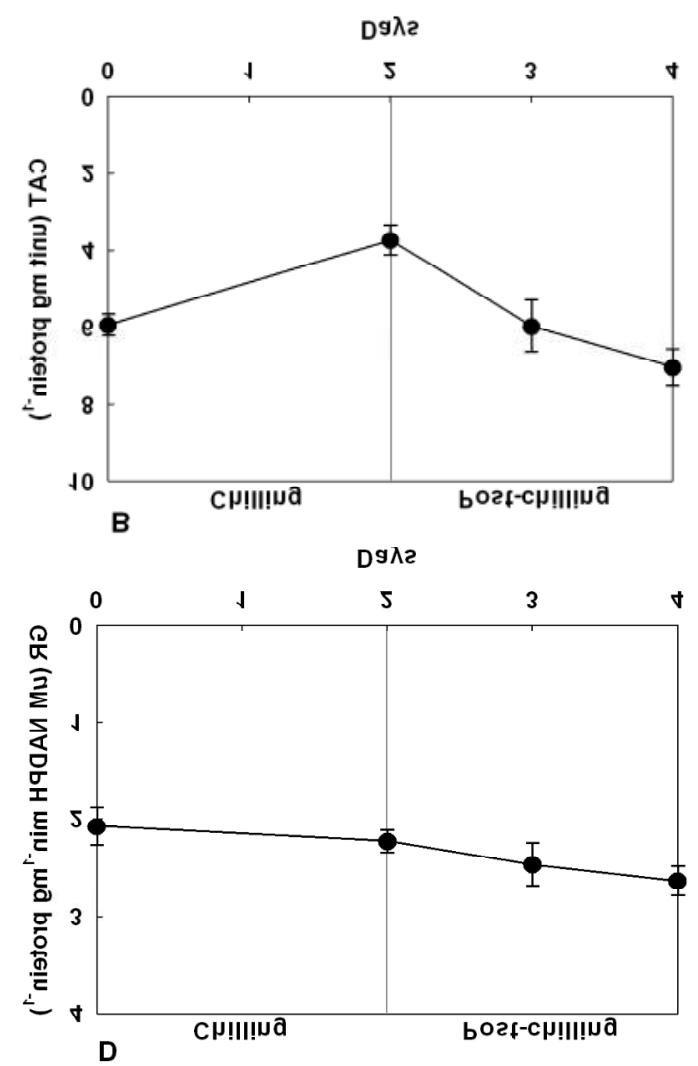

Fig. 4. Activaties of antioxidant enzymes in the rice leaves. A, SOD; B, CAT; C, APX; D, GR. The values represent mean \pm S.D. ( $n=6$ ). 
temperature as well as from its inactivation by the action of elevated $\mathrm{H}_{2} \mathrm{O}_{2}$ levels. APX activities were apparent increase during light-chilling and post-chilling (Fig. 4C). The activities of APX increased more than $50 \%$ as compared with control during 1 and 2 days of post-chilling. GR generates reduced GSH by NADPH-dependent reaction, which plays an important role in $\mathrm{H}_{2} \mathrm{O}_{2}$ scavenging mechanism. GR activity does change during light-chilling and post-chilling (Fig. 4D). GR activity increased gradually up to 2 days of chilling and even further increased during post-chilling.

Changes of isoforms of antioxidant enzymes by native PAGE

Native gels stained for the activities of SOD, CAT, APX and GR in the rice leaves were shown Fig. 5. Among three different SOD isoforms, only CuZn-SOD and Mn-SOD were detected by native PAGE, while Fe-SOD was not found in rice leaves (Fig. 5A). Moreover no significant differences were existed in SOD isoforms in rice leaves after light-chilling and post-chilling. When CAT isoforms were analyzed by native PAGE, from rice leaves that had been subjected to 2 days of light-chilling, it was shown that activities of isoform -2 and -3 were inhibited (Fig. 5B). In the contrast, activities of CAT isoform -2 and -3 were increased during
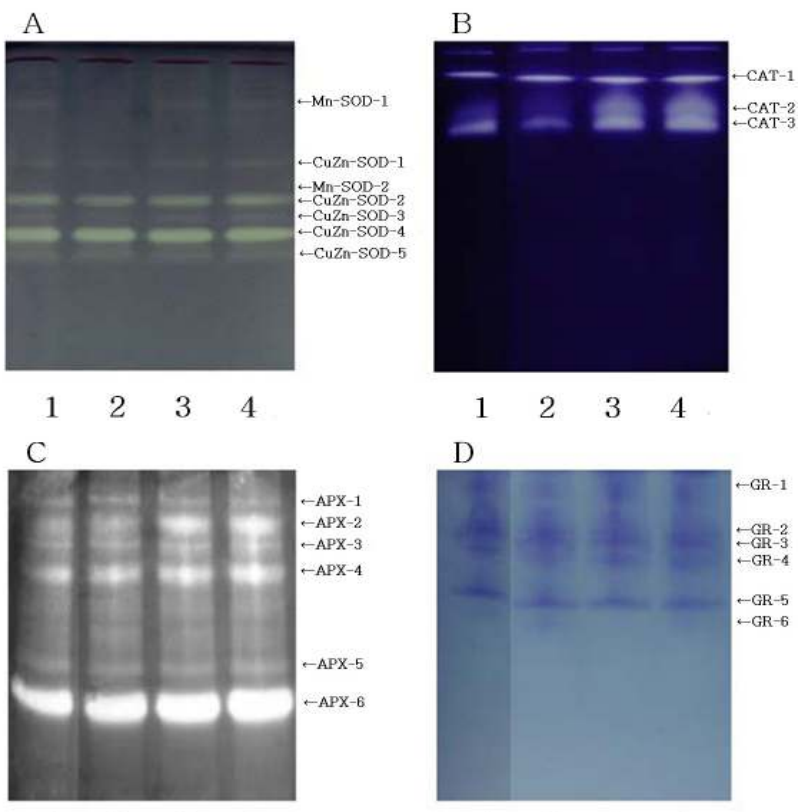

$\begin{array}{llll}1 & 2 & 3 & 4\end{array}$

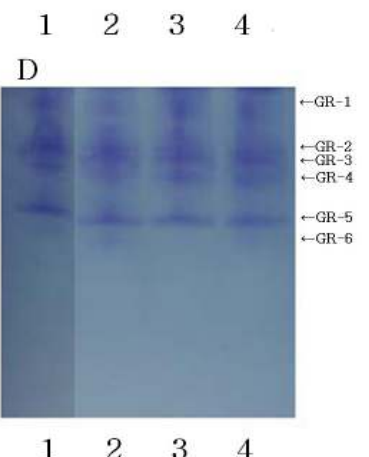

$\begin{array}{llll}1 & 2 & 3 & 4\end{array}$

Fig. 5. Native gel stained for the activity of SOD (A), CAT (B), APX (C) and GR (D) in the rice leaves. lane 1, control; lane 2, 2 days chilling to $4^{\circ} \mathrm{C}$; lane 3,1 day post-chilling to $25^{\circ} \mathrm{C}$; lane 4,2 days post-chilling to $25^{\circ} \mathrm{C}$.

1 and 2 days of post-chilling. APX activities of high-molecular weight isoforms increased during post-chilling, but no change during light-chilling (Fig. 5C). No changes in the activities of GR isoforms were shown on the gel analysis during light-chilling and post-chilling (Fig. 5D).

\section{Discussion}

Light-chilling for 2 days decreased $\mathrm{F}_{\mathrm{v}} / \mathrm{F}_{\mathrm{m}}$ in comparison with control (Fig. 1). The declined $F_{v} / F_{m}$ was quickly restored during post-chilling. Chilling-induced $F_{v} / F_{m}$ reduction was due to $F_{v}$ decrease, while $F_{o}$ tended to decrease slightly during light-chilling and post-chilling (Fig. 1). Degree of chilling damage for 2 days has been observed by chlorophyll fluorescence analysis which predicts effects of chilling before the appearance of visual chilling injury symptoms. After exceeding chilling stress for 2 days, rice leaves were not recovered which have been curled. Also, the senescence symptom shown a part of yellow observed after post-chilling for 2 days. Recovery of $F_{v} / F_{m}$ during post-chilling explains that photosynthetic apparatus was not subjected to irreparable damages by light-chilling for 2 days. Kim et al. [18] reported photosynthetic apparatus of rice was mostly down-regulated by light-chilling and the down-regulated functions were restored with $25^{\circ} \mathrm{C}$ recovery in darkness. Restoration of $F_{v} / F_{m}$ during post-chilling might be explained in terms of the decrease of discharged quencher and/or spillover. As mentioned above, primary damage due to light-chilling is caused by photooxidation from photoinhibition [2]. Increase in rate contents of non-photochemical process $\left(1 / F_{m}{ }^{\prime}\right)$ is also involved in the process (Fig. 2). Plants contain low-molecular weight antioxidants such as ascorbate or GSH as well as antioxidant enzymes such as SOD, CAT, APX and GR, especially activities of those antioxidant enzymes are interconnected. Chilling-induced oxidative stress symptoms are shown as changes in the amount of $\mathrm{H}_{2} \mathrm{O}_{2}$. The amount of $\mathrm{H}_{2} \mathrm{O}_{2}$ increased in rice leaves during light-chilling, but decreased during post-chilling (Fig. 3). $\mathrm{H}_{2} \mathrm{O}_{2}$ in chloroplasts is mostly generated by $\mathrm{O}_{2}^{-}$catalyzed by SOD [8]. Therefore, SOD increase during chilling for 2 days seems to be responsible for elevating levels of $\mathrm{H}_{2} \mathrm{O}_{2}$ (Fig. 4A and 5A). Superoxide dismutation by SOD is a basic phase of defense against chilling injury [11]. $\mathrm{H}_{2} \mathrm{O}_{2}$ is scavenged by APX, and CAT and GR is involved in APX activity. APX activity was increased during post-chilling (Fig. 4C). APX increase was observed in chilling-tolerant rice cultivars 
$[15,24]$. In a similar context, APX increase in rice with chilling might lead to the increase of defense capacity against oxidative stress. With respect to $\mathrm{H}_{2} \mathrm{O}_{2}$, changes in CAT activity were in contrast to APX. Decrease in the total activities of CAT was observed after 2 days of light-chilling, and that could be explained by the inhibition of CAT-2 and -3 isoforms (Fig. 4B and 5B). A marked decline in CAT activity have also been reported of rice plants during exposure to salt stress [22]. GR participating in $\mathrm{H}_{2} \mathrm{O}_{2}$ metabolism including APX is involved in the reduction of ascorbate, a substrate of APX [9]. GR activity showed gradual increase from chilling to post-chilling (Fig. 4D). GR is required for regeneration of ascorbate which is necessary for APX activity. In rice leaves, increase of APX and GR activity were indicates that GR is considerable relation to APX activity by light-chilling. The increase of GR activity was also observed in cold-stressed rice [15]. The increase of antioxidative system induced by drought and chilling is associated with the tolerance of rice to the stresses. To put all the results together, chilling reduces photochemical capacity of rice leaves, as shown in $F_{v} / F_{m}$ ratio reduction. Chilling can induce primary oxidative stress by ROS generation and this chilling-induced oxidative stress was detected by quantitative increase of $\mathrm{H}_{2} \mathrm{O}_{2}$. From these results, SOD may serve as a basis for defense against chilling injury, dismutating superoxide generated during light-chilling. From the APX activity and decreased CAT activity, we suggest that these two enzymes show mutual supplementary relationships, indicating different tendency in response to light-chilling.

\section{Acknowledgments}

This work was supported by a Korea Research Foundation Grant funded by the Korean Government (MOEHRD) (KRF-2005-070-C00128) and in part by Dong-eui University Research Grants in 2008.

\section{References}

1. Allen, D. J. and D. R. Ort. 2001. Impacts of chilling temperatures on photosynthesis in warm-climate plants. Trends in Plant Sci. 6, 36-42.

2. Aroca, R., J. J. Irigoyen, and M. Sanchez-Diaz. 2001. Photosynthetic characteristics and protective mechanisms against oxidative stress during chilling and subsequent recovery in two maize varieties differing in chilling sensitivity. Plant Sci. 161, 719-726.

3. Asada, K. 1992. Ascorbate peroxidase-a hydrogen peroxide scavenging enzyme in plants. Physiol. Plant 85, 235-241.

4. Asada, K. and M. Takahashi. 1987. Production and scavenging of activated oxygen in photosynthesis, pp. 227-287, In Kyle, D. J., C. B. Osmond, and C. J. Arntzen (eds.), Photoinhibition. Elsevier Science Publishers, Amsterdam, the Netherlands.

5. Asada, K. 1999. The water-water cycle in chloroplasts: scavenging of active oxygen and dissipation of excess photons. Annu. Rev. Plant Physiol. Plant Mol. Biol. 50, 601-639.

6. Beauchamp, C. and I. Fridovich. 1971. Superoxide dismutase: improved assays and an assay applicable to acrylamide gels. Anal. Biochem. 44, 267-291.

7. Beyer, W. F. and I. Fridovich. 1987. Assaying for superoxide dismutase activity: some large consequences of minor changes in conditions. Anal. Biochem. 161, 559-566.

8. Casano, L. M., L. D. Comez, H. R. Lascano, C. A. Gonzalez, and V. S. Trippi. 1997. Inactivation and degradation of CuZn-SOD by active oxygen species in wheat chloroplasts exposed to photooxidative stress. Plant Cell Physiol. 38, 433-440.

9. Creissen, G. P., A. Edwards, and P. M. Mullineaux. 1994. Glutathione reductase and ascorbate peroxidase, pp. 343-364, In Foyer, C. H. and P. M. Mullineaux (eds.), In Causes of Photooxidative Stress and Amelioration of defense systems in plants, Boca Raton, CRC Press.

10. Edwards, E. A., C. Enard, G. P. Creissen, and P. M. Mullineaux. 1994. Synthesis and properties of glutathione reductase in stressed peas. Planta 192, 137-143.

11. Fadzillah, N. M., V. Gill, R. P. Finch, and R. H. Burdon. 1996. Chilling, oxidative stress and antioxidant responses in shoot cultures of rice. Planta 199, 552-556.

12. Feierbend, J., C. Schaan, and B. Hertwig. 1992. Photoinactivation of catalase occurs under both high-and low-temperature stress conditions and accompanies photoinhibition of photosystem II. Plant Physiol. 100, 1554-1561.

13. Flowers, T. J. and A. R. Yeo. 1995. Breeding for salinity resistance in crop plants: where next? Aust. J. Plant Physiol. 22, 875-884.

14. Genty, B., J. -M. Briantais, and N. R. Baker. 1989. The relationship between the quantum yield phtosynthetic electron transport and quenching of chlorophyll fluorescence. Biochemica et Biophysica. 990, 87-92.

15. Guo, Z., W. Ou, S. Lu, and Q. Zhong. 2006. Differential responses of antioxidative system to chilling and drought in four rice cultivars differing in sensitivity. Plant Physiol. and Biochem. 44, 828-836.

16. Howarth, C. J. and H. J. Ougham. 1993. Gene expression under temperature stress. New Phytol. 125, 1-26.

17. Huang, M. and Z. Guo. 2005. Responses of antioxidative system to chilling stress in two rice cultivars differing in sensitivity. Biol. Plant. 49, 81-84.

18. Kim, J. -H., H. J. Hwang, H. -S. Park, C. B. Lee, K. Y. Myung, and C. H. Lee. 1997. Differences in the rate of dephosphorylation of thylakoid proteins during dark incubation after chilling in the light between two rice (Oryza sativa L.) varieties. Plant Sci. 128, 159-168. 
19. Krause, G. H. 1994. Photoinhibition induced by low temperatures, pp. 331-342, In Baker, N. R. and J. R. Bowyer (eds.), Photoinhibition of Photosynthesis, Bios Scientific Pub. Oxford.

20. Kyle, D. J. 1987. The biochemical basis for photoinhibition of photosystem II, pp. 197-225, In Kyle D. J., C. B. Osmond and C. J. Arntzen (eds.), Photoinhibition. Elsevier Science, New York.

21. Lee, D. H. and C. B. Lee. 2000. Chilling stress-induced changes of antioxidant enzymes in the leaves of cucumber: in gel enzyme activity assays. Plant Sci. 159, 75-85.

22. Lee, D. H., Y. S. Kim, and C. B. Lee. 2001. The inductive responses of the antioxidant enzymes by salt stress in the rice (Oryza sativa L.). J. Plant Physiol. 158, 737-745.

23. Lowry, O. H., N. J. Rosebrough, A. L. Fare, and R. J. Randall. 1951. Protein measurement with the folin phenol reagent. J. Biol. Chem. 193, 265-275.

24. Marin, E., L. Nussaume, A. Quesada, M. Gonneau, B. Sotta, P. Hugueney, A. Frey, and A. Marion-Poll. 1996. Molecular identification of zeaxanthin epoxidase of Nicotianan plumbaginifolia, a gene involved in abscisic acid biosynthesis and corresponding to the ABA loucs of Arabidopsis thaliana. J. EMBO 15, 2331-2342.

25. McKersie, B. D. 1991. The role of oxygen free radicals in mediating freezing and dessication stress in plants, pp. 107-118, In Pell, E. J. and K. L. Steffen (eds.), Active oxy- gen/oxidative stress and plant metabolism. American Society of Plant Physiologists, Rockville, MD.

26. Munns, R. 2002. Comparative physiology of salt and water stress. Plant Cell Environ. 25, 239-250.

27. Omran, R. G. 1980. Peroxide levels and activities of catalase, peroxide and indoleacetic acid oxidase during and after chilling cucumber seedling. Plant Physiol. 65, 407-408.

28. Oquist, G., W. S. Chow, and J. M. Anderson. 1992. Photoinhibition of photosynthesis represents a mechanism for long-term regulation of photosysthesis. Planta 186, 450-460.

29. Saruyama, H. and M. Tanida. 1995. Effect of chilling on activated oxygen-scavenging enzymes in low temperature-sensitive and -tolerant cultivars of rice (Oyza sativa L.). Plant Sci. 109, 105-113.

30. Taylor, A. O., C. R. Slack, and H. G. McPherson. 1974. Plants under climatic stress VI chilling and light effect on photosynthetic enzymes of sorghum and maize. Plant Physiol. 54, 696-701.

31. To, K. Y., D. F. Suen, and S. C. Chen. 1999. Molecular characterization of ribulose-1,5-bisphosphate carboxylase/oxygenase activase in rice leaves. Planta 209, 66-76.

32. Van Camp, I. and M. Van Montagu 1997. The regulation and function of tobacco superoxide dismutases. Free Rad. Biol. Med. 23, 515-520.

\section{초록 : Light-chilling에 의해 유도된 벼 잎에서의 광합성 변화와 항산화 효소의 반응 \\ 구정숙·추연식'이진범* \\ (동의대학교 분자생물학과, ${ }^{1}$ 경북대학교 생물학과)}

대부분의 열대 식물은 chilling에 민감하게 반응한다. 대표적 열대 식물인 벼 잎에 대한 light-chilling 처리와 이 후의 회복기(post-chilling) 동안 일어나는 반응들을 알아보았다. Chilling 시 벼 잎에서의 광합성 효율 $\left(\mathrm{F}_{\mathrm{v}} / \mathrm{F}_{\mathrm{m}}\right)$ 은 대조구보다 $50 \%$ 감소하였고, 상대적으로 $\mathrm{H}_{2} \mathrm{O}_{2}$ 양은 $48 \%$ 증가하였다. 항산화 효소들 중 $\mathrm{SOD}$ 와 GR 활성은 chilling 과 post-chilling 시 증가하였다. 특히 SOD isoforms의 경우 CuZn-SOD와 Mn-SOD 가 발현된 반면 Fe-SOD는 발현되지 않았다. CAT 활성은 chilling 시 감소하였으며, 반면에 APX는 크게 증가하였다. Chilling 시 CAT의 isoforms의 변화를 보면, CAT-2와 -3의 활성이 감소한 것과 대조적으로 post-chilling 시 이들 isoforms의 활성은 증가하 였다. 이처럼 APX와 CAT 활성은 벼 잎이 chilling stress를 격게 될 때 상반되는 변화를 보여주었다. 